\title{
The genus Cycas (Cycadaceae) in The Philippines
}

\author{
A.J. Lindstrom ${ }^{1}$, K.D. Hill ${ }^{2}$ and L.C. Stanberg ${ }^{2}$ \\ ${ }^{1}$ Nong Nooch Tropical Botanical Garden, Sattahip, Chonburi 20250, Thailand \\ ${ }^{2}$ National Herbarium of New South Wales, Royal Botanic Gardens, Mrs Macquaries Road, Sydney \\ 2000, Australia
}

\begin{abstract}
The genus Cycas is reviewed for The Philippines. Ten species are enumerated, with five described as new (Cycas saxatilis, C. aenigma, C. vespertilio, C. nitida and C. lacrimans). C. wadei, C. curranii and C. saxatilis are placed in the new Section Wadeae. Lectotypes are chosen for Cycas circinalis subsp. riuminiana var. curranii forma graminea J.Schust. and Cycas circinalis subsp. riuminiana var. curranii forma maritima J.Schust. The species are placed within an infrageneric classification previously outlined. Distribution of all taxa is mapped, conservation status is discussed and a key to species provided. Previous recordings of C. circinalis and C. rumphii from The Philippines are discussed.
\end{abstract}

\section{Introduction}

The genus Cycas is the single constituent genus of the family Cycadaceae, itself the basal lineage of the living cycads (Stevenson, 1992). It is also the sole living cycad group occurring in Asia. The only known fossil evidence for this genus is from the Eocene of China and Japan, and this, together with the occurrence of all major lineages in the genus in mainland Asia, supports a long-term presence and probable origin of this genus in that region (Hill 1995). Cycas consists of about 100 species, chiefly IndoChinese (about 40 species) and Australian (27 species). The genus also occurs in the Malesian region, Japan and India, extending to Micronesia and Polynesia, Madagascar and East Africa. Plants are commonly understorey shrubs in forest, woodland or savanna habitats. Ten species are known in The Philippines.

The cycad flora of The Philippines is relatively sparse in comparison to Indochina and northern Australia, both of which show extensive local radiations. The Philippines is however notable for the occurrence of the endemic relictual section Wadeae, which shows links to Mainland Asian groups and has probably been separated by crustal rifting in the early Tertiary.

The present work is the outcome of our separate and combined studies, with a total of three field trips during the period 2000-2007. Herbarium collections held by A, B, BM, BO, E, K, G, L, LAE, LBC, NY, P and SING have been examined by at least one author. Authorship of new taxa is as stated in species descriptions. Terminology is as in previous papers in this series (e.g. Hill 1994), as are generic and specific concepts followed. 
Conventions in measurements taken and presented in the following descriptions are as in other papers in this series, and are set out in Lindstrom and Hill (2007). Nomenclature follows the latest version of the International Code of Botanical Nomenclature [ICBN] (McNeill et al. 2006).

\section{Conservation}

Populations of many Asian species appear to have declined, sometimes dramatically, over the past century. However, there is no comparative data to support this impression, and evidence for the decline is largely anecdotal and circumstantial. Several causative factors for this decline can be observed in action today, however, even though quantitative data on the effects are not available. Two principal threats to cycads exist in The Philippines at present: habitat loss and selective removal of plants from the wild for trade or utilization. Some but not all species occur in reserved areas already proclaimed, but enforcement within these areas is sometimes difficult. There is, however, a growing interest in habitat and species conservation within The Philippines, and additional reserved areas are being evaluated and declared.

Another, more uncontrollable threat is the rapid spread of Aulacaspis scale insect (Howard et al. 1999). The scale seems to be controlled naturally by native predators on Palawan (C. curranii, C. saxatilis) and Culion (C. wadei) but is seriously affecting large numbers of cultivated cycads on Luzon, Negros and Panay. It has yet to be confirmed if the scale has spread into wild populations but historically known populations of C. edentata are now gone and cultivated plants in the near vicinity are dying from the scale. It seems that there is no natural predator in existence on these islands and the spread of the scale into wild populations and further to other islands as yet not affected would be of serious consequences to many endemic Philippine cycads.

Two Philippine species (C. chamberlainii, C. wadei) were listed in the now out-of-date (for this region) IUCN 1997 Red Book of Threatened Plants (Walter \& Gillet 1998). Species treated below are allocated provisional conservation status codes under the new coding system devised by the IUCN (IUCN 2001). Conservation status of all species is summarised in Table 1.

\section{Taxonomic history}

The genus Cycas was first recorded from The Philippines by Regel (1863), with his description of $C$. riuminiana from cultivated plants imported from Manila. Four Philippine taxa were listed by Merrill (in Foxworthy 1911): C. circinalis, C. revoluta, C. sp. aff. cairnsiana (now C. wadei) and C. sp. Palawan (now C. curranii). The same four species were listed by Merrill in 1923, but now with the name C. cairnsiana incorrectly assigned to the species from Culion. Plants from Mt Arayat in Luzon were described as C. chamberlainii in 1925, and the plants from Culion were described as C. wadei in 1936.

The next discussion of the cycads of the region was by Zamora and Co (1979), listing four species, C. revoluta, C. circinalis, C. wadei and C. chamberlainii. This was followed by Amoroso (1986), with 5 species, C. revoluta, C. circinalis, C. wadei, C. chamberlainii and C. rumphii. This was the first acknowledgement that a species of the Cycas rumphii group was present in the Philippines, and the first clear separation of the two species treated below as C. riuminiana (C. circinalis sensu Amoroso) and C. edentata (C. rumphii sensu Amoroso). 
$\frac{ \pm}{2}$
$\frac{0}{0}$
$\frac{0}{10}$

㩆䨌

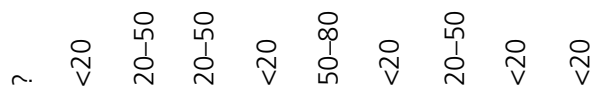

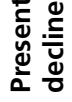

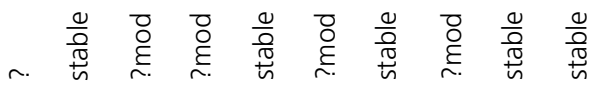

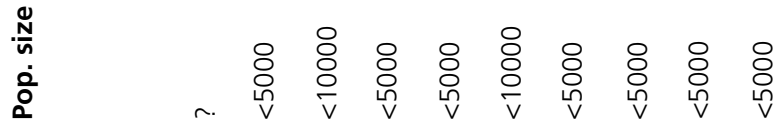

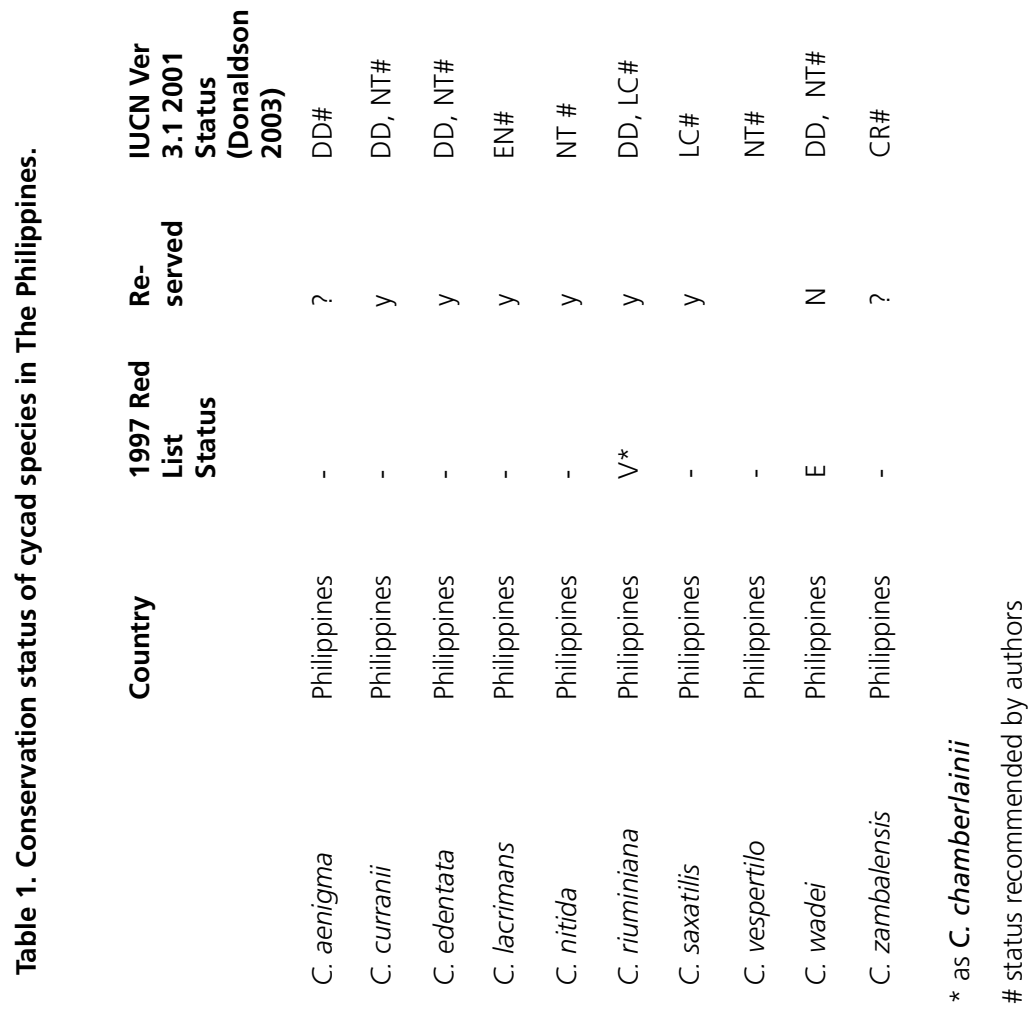


The account by de Laubenfels and Adema (1998) records four species from the Philippines, C. silvestris, C. wadei, C. edentata and C. riuminiana. C. chamberlainii is included in the synonymy of $C$. riuminiana, and their interpretation of $C$. silvestris (here regarded as an Australian endemic) includes material treated below under C. curranii, C. riuminiana and C. edentata. Only the name C. wadei is wholly correctly applied by these authors.

Madulid and Agoo described the endemic C. zambalensis in 2005.

\section{Taxonomic treatmant}

CYCAS L., Sp. Pl.: 1188 (1753).

Lectotype: C. circinalis L.; designated by Stevenson in Jarvis et al. (1993).

Dioecious palm-like shrubs with aerial or subterranean, pachycaul, cylindrical stems clad with persistent frond-bases. Fronds loosely pubescent when young, pinnate, spirally arranged, produced in seasonal growth flushes interspersed with cataphylls, lower pinnae often reduced to spines. Longitudinal ptyxis erect or rarely reflexed, horizontal ptyxis circinate. Pinnae with a single thick midrib and no lateral veins; stomata confined to abaxial surface in most species; individual ptyxis involute. Trichomes microscopically transparent, branched or simple. Leaves with vascular traces girdling stems, girdling traces not present in cataphylls or megasporophlls. Microsporophylls aggregated into determinate cones and bearing numerous microsporangia (pollen-sacs) on abaxial surfaces, with a simple sterile apex, which is often produced into an upturned spine; microsporangia opening by slits; pollen cymbiform, monosulcate. Megasporophylls spirally arranged in an indeterminate terminal rosette with the central axis continuing vegetative growth. Ovules two to many (rarely one), marginally inserted on the stipe and directed obliquely outwards ('ascending'); sporophyll apically dilated into a pinnatifid, pectinate, toothed or entire lamina. Seeds with a yellow, orange or brown fleshy outer sarcotesta, and with or without spongy tissue beneath the inner woody sclerotesta. Endosperm haploid, derived from the female gametophyte. Embryo straight; with 2 cotyledons that are usually united at the tips and a very long, spirally twisted suspensor; seeds platyspermic; germination cryptocotylar.

Six sections are now recognised; four in Hill (1995), an additional one in Hill (2008) and another one in this paper. There has been disagreement on subgeneric division (Wang 1996, de Laubenfels 1998) and, in the light of improved understanding of the genus, none of the proposed systems would appear entirely adequate (Hill 1998, 2004a, Hill 2004b). Two clear groups, regarded below as sections, occur naturally in The Philippines, and a third is represented by one widely cultivated species. 


\section{Key to sections}

1 Ovules tomentose Section \#Asiorientales

$1^{\star}$ Ovules glabrous

2 Male sporophylls soft \& waxy, lacking an upturned apical spine; seeds with a pronounced longitudinal ribbing. Section Wadeae

$2^{\star}$ Male sporophylls hard, with a distinct apical spine; seeds smooth Section Cycas

\section{Key to species}

1 Ovules and seeds tomentose; leaflet margins strongly recurved \#C. revoluta

$1^{\star}$ Ovules and seeds glabrous; leaflet margins not strongly recurved

2 Male cones soft, waxy; sclerotesta strongly ribbed

3 Seeds small; $<40 \mathrm{~mm}$ long

4 Leaflets $3-8 \mathrm{~mm}$ wide 1. C. wadei

$4^{\star}$ Leaflets $10-14 \mathrm{~mm}$ wide 3. C. saxatilis

$3^{\star}$ Seeds large; $\geq 40 \mathrm{~mm}$ long 2. C. curranii

$2^{\star}$ Male cones firm; sclerotesta not ornamented

5 Lateral spines on megasporophylls distinct

6 Apical lamina of megasporophyll $<80 \mathrm{~mm}$ long

7 Leaflets stiff, narrow (5-8 mm wide), leaves keeled, petiole tomentose 8. C. zambalensis

$7^{\star}$ Leaflets wider (> $7 \mathrm{~mm}$ ), lax, leaves flat, petiole not tomentose 8 Megasporophyll with 2 broad wing-like lateral processes

6. C. vespertilio

$8^{\star}$ Megasporophyll with more than 8 lateral spines

9 Littoral species, thick spongy endotesta present 10. C. nitida $9^{*}$ Inland forest species, spongy endotesta absent or thin

10 Leaves flat in section 5. C. riuminiana

$10^{\star}$ Leaves lax and drooping in section 7. C. lacrimans

$6^{\star}$ Apical lamina of megasporophyll $>80 \mathrm{~mm}$ long 4. C. aenigma

$5^{\star}$ Lateral spines on megasporophylls indistinct 9. C. edentata

\# this species, native to Japan and China, is widely cultivated throughout The Philippines. It is not discussed any further in this treatment. 


\section{A. Section WADEAE}

Cycas section Wadeae K.D.Hill \& A.Lindstrom, sect. nov.

Inter genus sclerotesta valde longitudinaliter costata distinguenda.

Cycas section Indosinenses subsection Wadeanae K.D.Hill, abstract in Programme for Cycad 93 Third International Conference on Cycad Biology 15-16 (1993), nom. nud.

Cycas section Panzhihuanenses subsection Wadeanae (K.D.Hill) D.Y.Wang, Cycads China 27 (1996), nom. inval.

Type: C. wadei Merr.

This section is defined by the soft, waxy male cones and microsporophylls, the pectinate megasporophyll apices, the glabrous ovules, and the yellow seeds with a non-fibrous sarcotesta and a strongly longitudinally ribbed sclerotesta. The group is taxonomically somewhat isolated and includes only three Philippine endemic species.

1. Cycas wadei Merrill, Philipp. J. Sci. 60(3): 234-236, Pl. 1-4 (1936).

Type: Philippines, Luzon, Culion, Cogonal Grande,W.H. Brown s.n. (iso NY, GH, B, G, $\mathrm{K}, \mathrm{L}, \mathrm{MO}, \mathrm{P}$ ). The holotype at PNH is missing (or was destroyed in WW2).

Cycas circinalis subsp. riuminiana var. curranii forma graminea J. Schust., Pflanzenr. 99: 69 (1932).

Lectotype (here designated): Philippines, Luzon, Culion Island, Halsey Harbor near 'Holsey Harbor' (Halsey Harbour), 11 Feb 1902, E.D. Merrill 657 (lecto NY; isolecto K, L, US). There is no indication by Schuster that he saw any of these sheets and his main material may or may not have been destroyed in Berlin during WW2 hence a lectotype has been chosen.

Literature: Foxworthy (1911, as C. sp. aff. cairnsiana and C. sp. (Culion)), Merrill (1923, as C. cairnsiana), Dehgan and Yuen (1983), Zamora and Co (1986), Amoroso (1986).

Illustrations: Merrill (1936), Amoroso (1986).

Etymology: honouring US-born medical doctor working in the Philippines Dr H.W. Wade, the person who brought this species to the attention of its author.

Vernacular: Tagalog_bayit (pref. to bait, vait), oliva (plant, pref. to oliba, uliba, uliva), pitógo (seed, pref. to bitogo, patubo, pitugo, potago) (Amoroso 1986, Bonta \& Osborne 2007).

Stems arborescent, to $5 \mathrm{~m}$ tall, $10-20 \mathrm{~cm}$ diam. at narrowest point; 30-100 leaves in crown. Leaves deep green or grey-green, semiglossy $75-180 \mathrm{~cm}$ long, slightly to moderately keeled in section (opposing pinnae inserted at $90-150^{\circ}$ on rachis), with 160-208 leaflets, tomentum shedding as leaf expands or partly persistent; rachis usually terminated by a spine, $2-30 \mathrm{~mm}$ long; petiole $20-40 \mathrm{~cm}$ long, glabrous, spinescent for $60-100 \%$ of length; basal leaflets not gradually reducing to spines $80-180 \mathrm{~mm}$ long. Median leaflets simple, strongly discolorous 150-290 mm long, 3-8 mm wide, inserted at $50-60^{\circ}$ to rachis, narrowed to $2.5-3 \mathrm{~mm}$ at base (to $35-40 \%$ of maximum width), 5-8 $\mathrm{mm}$ apart on rachis; section flat or slightly keeled; margins flat; apex aristate, spinescent; midrib raised above, flat below, narrow. Cataphylls narrowly triangular, soft, pilose, 70-90 mm long. Pollen cones fusiform, green or cream, 40-70 cm long, 7-10 cm diam.; microsporophyll lamina waxy, not dorsiventrally thickened, 21-30 mm long, 
15-18 mm wide, fertile zone $25 \mathrm{~mm}$ long, sterile apex $6 \mathrm{~mm}$ long; apical spine absent or rudimentary, deflexed. Megasporophylls 14-22 cm long, brown-tomentose; ovules 2-4, glabrous; lamina orbicular, 70-100 $\mathrm{mm}$ long, 55-80 mm wide, deeply pectinate, with 20-30 soft lateral spines 14-35 mm long, 1-2 mm wide; apical spine distinct from lateral spines, 26-45 mm long, 9-14 $\mathrm{mm}$ wide at base. Seeds subglobose to ovoid, 17-40 mm long, 15-30 mm wide; sarcotesta yellow, not pruinose, 3-4 mm thick, fibrous layer absent; sclerotesta longitudinally ribbed; spongy endotesta absent.

Historical notes: described as a new species in 1936 by American botanist E.D. Merrill. This species was first reported by Foxworthy (1911), who recorded it as sp. aff. C. cairnsiana on the basis of observations and collections made by Merrill, who had collected sterile material on an excursion inland from Halsey Harbour on 11 Feb 1902 (Merrill 657), and observed that his collection most resembled material of C. cairnsiana when at Kew in 1908 (op. cit.). Merrill also later recorded this species as possibly being C. cairnsiana (1923), although the same year, he obtained more complete material via Dr Wade that clearly showed that the two were not the same. Wade had transplanted a number of plants to the Culion leper colony, and from them seeds were furnished to the botanic gardens at Kew, New York and Berlin.

Schuster (1932) attached an unwieldy and quite nonsensical quadrinomial to this taxon, using Merrill's original collection (Merrill 657) as the type. In placing this within his elaborate hierarchy under $C$. circinalis, he showed just how little he understood of this plant, which in fact belonged in a different section of the genus as he had divided it.

Merrill in the meantime had received more material from DrA.W. Herre of Culion, which prompted him to look more closely at this taxon. On obtaining more comprehensive collections from W.H. Brown and realising its very distinctive nature, he described it as a new species in 1936, designating the Brown material as 'the type collection'. There has been little subsequent disagreement with this recognition, although Zamora and Co (1986) listed plants from Palawan under C. wadei that are quite distinct (see C. curranii).

Seeds have been quite widely distributed over the years, and a number of mature plants are present in collections around the world. Fairchild Tropical Garden in Miami has been distributing seeds from their cultivated plants in recent years. Large quantities of seed collections from the wild were distributed in the early 1990's, and plants from these are now abundant in cultivation.

Distinguishing features: readily distinguished by the combination of the symmetrically ribbed sclerotesta and the narrow leaflets. C. curranii shares the ribbed sclerotesta, although seeds of the latter are twice as large as those of C. wadei. C. curranii also has leaflets that are about twice as broad. C. saxatilis also has wider leaflets and less keeled leaves.

Distribution and habitat: known only from Culion Island (Fig. 1), on low hills inland from Halsey Harbour on the west of the island. It occurs in a large open area of Imperata grassland locally known as the 'cogonal grande' or 'patag grande'. This is a seasonally dry area that suffers frequent grassfires, and the narrow leaflets would appear to be a parallel adaptation to seasonally xeric conditions similar to that seen in Australia (C. cairnsiana, C. calcicola) and India (C. beddomei).

Conservation status: although restricted, the population numbers in excess of 5000 plants, exhibits no signs of decline, and shows active recruitment with all age classes well represented. However, the land is apparently privately owned and not secure in any 
way. Although at present not threatened, any change in land use could seriously affect the conservation status of this species. Ver 3.1:IUCN (2001) status is DD (Donaldson 2003). Recommended status would be NT.

Selected specimens: PHILIPPINES: Culion: Brown s.n. (GH); Cogonal Grande, Herre 1061, 27 Apr 1931 (A); Patag, Fernando 1611, 1612, 22 Jun 2001 (LBC).

Mindoro: Oriental prov., Mansalay, fide Zamora \& Co (1986); no voucher. Cult.: Manilla, Fenix 121, 12 Apr 1938 (A); Inst Sci. Manilla, Quisumbing PNH 4476, 10 May 1948 (L); Inst Sci. Manilla, Quisumbing PNH 12163, 8 Dec 1953 (A); Manilla, Quisumbing PNH 16845, Jul 1953 (A).

2. Cycas curranii (J.Schust.) K.D.Hill, Proc. Third Int. Conf. Cycad Biol.: 150 (1995).

Cycas circinalis subsp. riuminiana var. curranii J.Schust., Pflanzenr. 99: 69 (1932).

Type: Philippines, Palawan, Molinao River, on river bank, Mar 1906, H.M. Curran 3842 (iso $\mathrm{K}, \mathrm{P}$ ). The holotype at PNH is missing (or was destroyed in WW2) and there is no way of knowing whether Schuster had other material at Berlin that also may have been destroyed during WW2.

Literature: Foxworthy (1911, as C. sp. Palawan), Merrill (1923, as C. sp. Palawan), Zamora \& Co (1986, as C. wadei in part).

Illustrations: Zamora and Co (1986), Foxworthy (1911 as C. sp. Palawan, Plate XXVII)

Etymology: honouring US-born forester Hugo M. Curran, collector of the type specimen.

Stems arborescent, to 1-8 $\mathrm{m}$ tall, $14-25 \mathrm{~cm}$ diam. at narrowest point; growing in soil or humus; base not strongly swollen; bark thick and corky; 30-120 leaves in crown. Leaves deep green or grey-green, highly glossy to semiglossy, 180-260 cm long, slightly keeled or flat (not keeled) in section, opposing leaflets inserted at $150-180^{\circ}$ on rachis), with 150-360 leaflets, with white or orange tomentum shedding as leaf expands; rachis usually terminated by paired leaflets; petiole $35-55 \mathrm{~cm}$ long (15-30\% of total leaf), glabrous, spinescent for $70-100 \%$ of length; basal leaflets not gradually reducing to spines, 90-230 mm long. Median leaflets simple, strongly discolorous, $210-310 \mathrm{~mm}$ long, $10-14 \mathrm{~mm}$ wide, inserted at $40-80^{\circ}$ to rachis, narrowed to $2.5-3 \mathrm{~mm}$ at base (to $15-30 \%$ of maximum width), $10-16 \mathrm{~mm}$ apart on rachis; section flat; margins flat, not undulate; apex acute, not spinescent; midrib raised above, flat below, narrow. Cataphylls narrowly triangular, soft, pilose, 100-130 mm long. Pollen cones fusiform, green or cream; microsporophyll lamina soft, not dorsiventrally thickened; raised; apical spine absent or rudimentary, deflexed. Seed cones closed at pollination, closed at seed set. Megasporophylls c. $21 \mathrm{~cm}$ long, grey-tomentose, tomentum shedding; ovules 2-6, glabrous; lamina orbicular, c. $100 \mathrm{~mm}$ long, c. $70 \mathrm{~mm}$ wide, deeply pectinate, with c. 32 soft lateral spines c. $20 \mathrm{~mm}$ long, c. $5 \mathrm{~mm}$ wide; apical spine distinct from lateral spines, c. $15 \mathrm{~mm}$ long, c. $17 \mathrm{~mm}$ wide at base. Seeds subglobose to ovoid, c. $48 \mathrm{~mm}$ long, c. $40 \mathrm{~mm}$ wide; sarcotesta yellow, not pruinose, fibrous layer absent; sclerotesta longitudinally ribbed; spongy endotesta absent.

Historical notes: the first record of a distinctive cycad from Palawan was by American Botanist Merrill, who recorded a distinctive species without a name from Palawan, collected by Curran in 1906 (in Foxworthy 1911, Merrill 1923). German botanist Julius Schuster devised the above quadrinomial based on the same specimen (1932). 
This in no way reflects the relationships and affinities of C. curranii, and this taxon was generally ignored subsequently until raised to species rank in 1995 by Hill. Zamora and Co (1986) listed plants from Palawan as C. wadei, a closely related species. De Laubenfels and Adema (1998) included material of C. curranii with quite unrelated material in a confused circumscription of $C$. silvestris (here regarded as an Australian endemic).

Large quantities of large seeds from the wild were distributed in the early 1990's, and plants from these are now abundant in cultivation.

Distinguishing features: readily distinguished by the combination of the symmetrically ribbed sclerotesta and the broad leaflets. Only C. wadei shares the ribbed sclerotesta, although seeds are half as large as those of $C$. curranii, and leaflets are narrower.

Distribution and habitat: known only from Palawan Island, apparently an ultramafic endemic, mostly on steep slopes on ultramafics, occasionally on alluvial outwash from ultramafic hills. This species occurs as an understorey plant in rich mixed closed forests, and has been recorded from Puerto Princessa, Aborlan and Narra municipalities (Fig. 1).

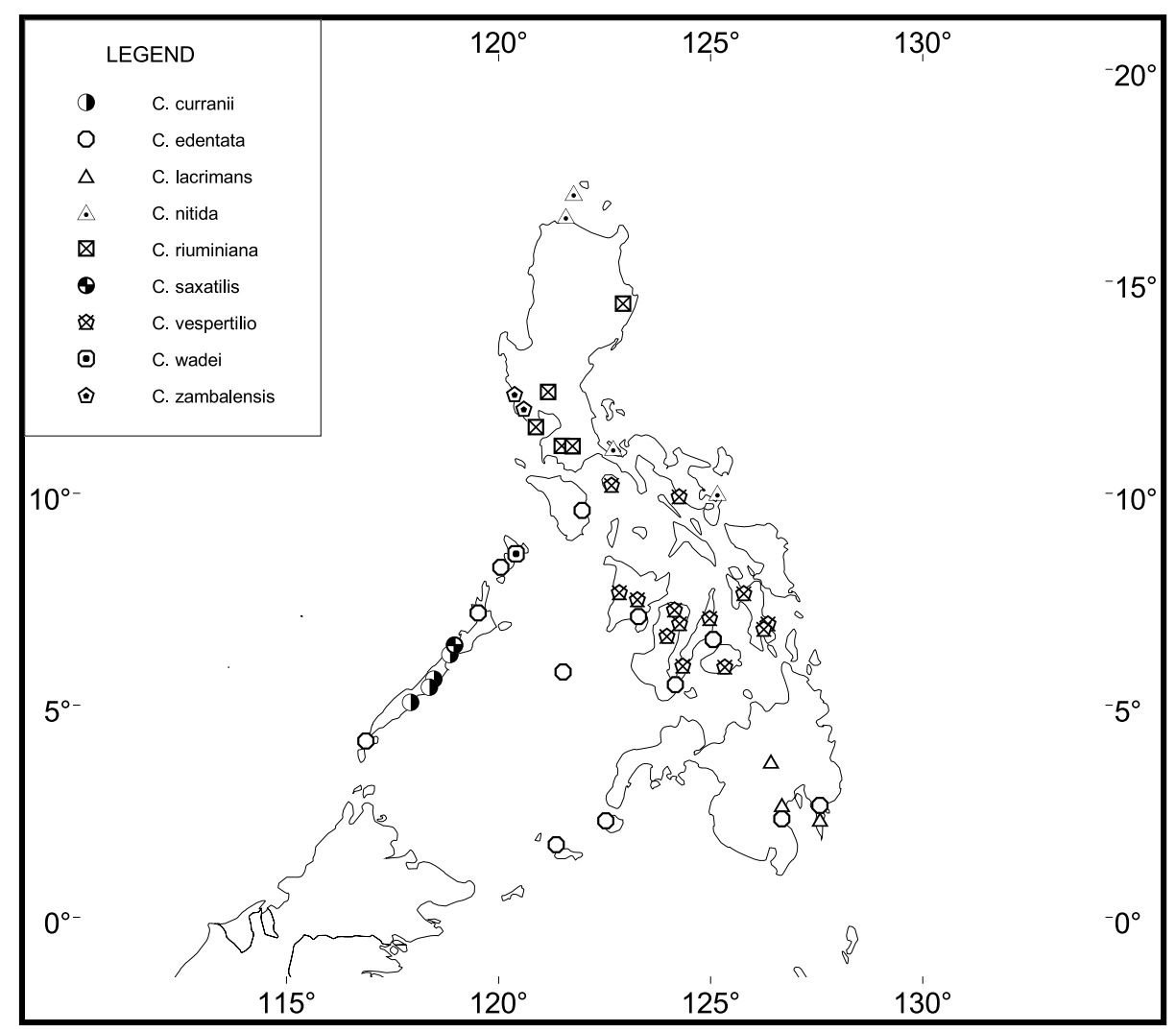

Fig. 1. Distribution of the genus Cycas in The Philippines. 
Conservation status: widespread over a considerable area, although typically in low population densities. The forest habitat is disturbed in areas at lower elevation and near the coastal plain, but more intact further inland, and large populations probably remain. Ver 3.1:IUCN (2001) status is DD (Donaldson 2003). Recommended status would be NT.

Selected specimens: PHILIPPINES: Palawan: Narra, Mt Victoria, Trident Mining Co area, alluvial fan at base of ultrabasic mountain, Podzorski SMHI 2119, 19 May 1984 (L); Narra, Upper Lapu Lapu (old trident mining area), Fernando 1613, 26 Jun 2001 (LBC); Narra, cult. in Antiputuan village, collected from hills to west, Fernando 1614, 26 Jun 2001 (LBC); Aborlan, Tabyay River, Baranguy Cabigaan locality, Fernando 1615, 26 Jun 2001 (LBC).

\section{Cycas saxatilis K.D.Hill \& A.Lindstrom, sp. nov.}

Inter species sectionem Wadearum habitatione in rupibus calcareis, strobilis masculis angustioribus praelongisque, microsporophyllis apice non spinosis, megasporophyllis reductis spinis apicalibus elongatis instructis distinguitur.

Type: Philippines, Palawan, St Pauls Bay, major outcrop to SE, pendulous on limestone cliff face, Podzorski SMHI 2035, 6 Apr 1984 (holo L).

Etymology: from the Latin saxatilis, dwelling among rocks, in reference to the soil-free cliff-face habitat.

Stems arborescent, to $0.5-4 \mathrm{~m}$ tall, $20-25 \mathrm{~cm}$ diam. at narrowest point,; growing on bare vertical cliffs; base not strongly swollen; bark thin and smooth. Leaves bright green, highly glossy, 160-190 cm long, slightly keeled or flat in section (opposing leaflets inserted at c. $150^{\circ}-180^{\circ}$ on rachis), with $170-380$ leaflets, tomentum shedding as leaf expands; rachis consistently terminated by paired leaflets; petiole $40-60 \mathrm{~cm}$ long (25-35\% of total leaf), glabrous, spinescent for $50-90 \%$ of length; basal leaflets not gradually reducing to spines, $150-230 \mathrm{~mm}$ long. Median leaflets simple, strongly discolorous, $220-340 \mathrm{~mm}$ long, $9-12 \mathrm{~mm}$ wide, inserted at $50-75^{\circ}$ to rachis, decurrent for 3-5 mm, narrowed to $2.5-3 \mathrm{~mm}$ at base (to $20-25 \%$ of maximum width), 10-17 mm apart on rachis; section flat; margins flat, or slightly recurved, not undulate; apex acute, not spinescent; midrib raised above, raised below, narrow. Pollen cones ovoid, cream or green, c. $49 \mathrm{~cm}$ long, c. $5 \mathrm{~cm}$ diam; microsporophyll lamina soft, not dorsiventrally thickened; level; apical spine rudimentary, upturned. Megasporophyll and seeds not seen. Fig. 2.

Distinguishing features: it distinguished from all other species in the region by the limestone cliff habitat, the narrow pollen cones with no apical spines on microsporophylls. .

The type specimen consist of leaves and a male cone which most closely matches C. curranii. C. curranii is tall growing and erect on serpentine soil in rainforest. however the plants that were observed growing at St Pauls Bay are pendulous on limestone cliffs in exposed places and this field observation has lead to the conclusion that they are two different taxa, even though complete material of $C$. saxatilis (i.e. female cones and seeds) have not been seen.

Distribution and habitat: known only from limestone outcrops of the St Pauls Mountain massif on Palawan (Fig. 1). This species grows in crevices in vertical limestone cliffs with no soil. 
Conservation status: although it is known from a single locality, this mountain area is quite extensive, and plants are abundant in large, undisturbed populations in the most inaccessable sites. Most of the range is also included in the St Pauls Bay National Park. This species is not regarded as a threatened species. Recommended Ver 3.1:IUCN(2001) status would be $\mathbf{L C}$.

Selected specimens: PHILIPPINES: Palawan: Road to St Pauls Bay, Hill \& Lindstrom s.n., 25 Jun 2001 (sight record only, no voucher).

\section{B. Section CYCAS}

Section Lemuricae J.Schust., Pflanzenr. 99: 65 (1932), nom. illegit.

Section Cycas is defined by the combination of glabrous ovules and a non-pectinate megasporophyll lamina. Three subsections are recognised, circumscription following Hill (1995), with two occurring in The Philippines. The full range of the section is from India and southern Indochina south to Australia, and from East Africa east to Tonga.

\section{Key to the Subsections of Section Cycas occurring in The Philippines}

1 Seeds with a thick (buoyant) spongy layer inside the sclerotesta ....... Subsection Rumphiae

$1^{\star}$ Seeds with a thin (not buoyant) or absent spongy layer Subsection Cycas

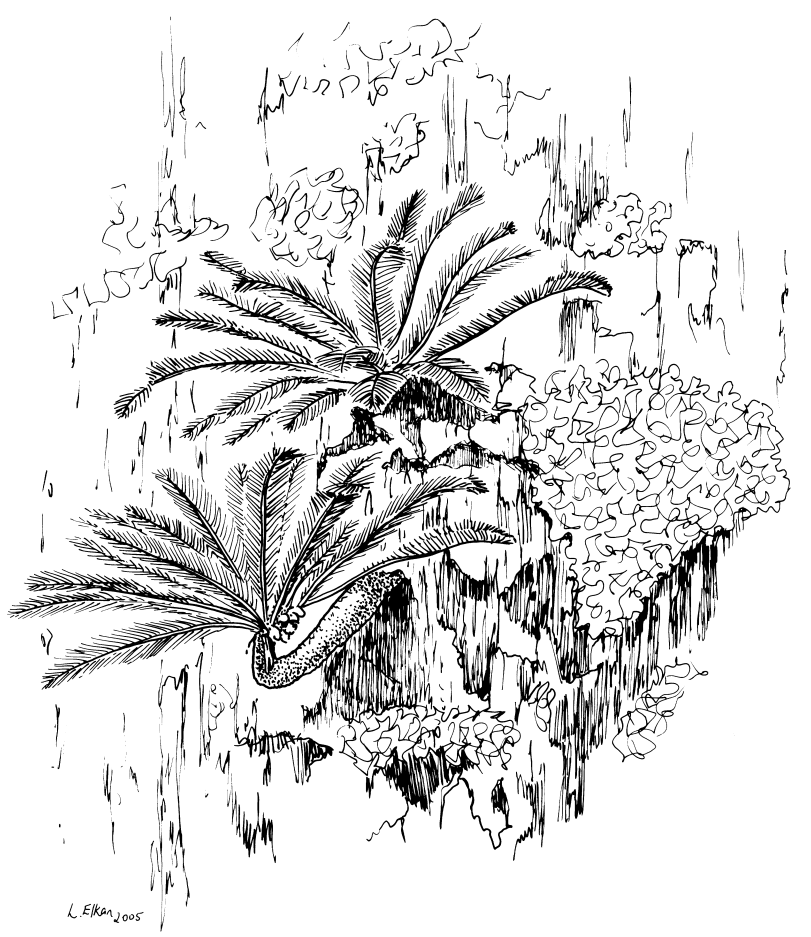

Fig. 2. Cycas saxatilis. Habitat sketch (from K. Hill slide 25.06.2001, Hill \& Lindstrom s.n.). No scale. 


\section{Cycas subsection Cycas}

This subsection of about 15 species is defined by the absence of a spongy endotesta, and the narrow megasporophyll lamina. It ranges from India and Sri Lanka to Luzon, south and east to New Guinea. Most representatives are plants of closed forests, usually on ridges away from the coast. Five species occur in The Philippines.

\section{Cycas aenigma K.D.Hill \& A.Lindstrom, sp. nov.}

Inter species philippinenses combinatione characterum sequentium distinguitur: strobili masculi robusti; microsporophylla apice spinis magnis longioribus robustisque; megasporophylla apice elongato attenuatoque et spinis lateralibus elongates instructa.

Type: Philippines, Palawan, cult. Puerto Princessa city, Fernando 1617, 26 Jun 2001 (holotype LBC).

Etymology: from the Latin aenigma, to speak darkly, the root of the Engish word enigma, a thing which cannot be satisfactorily explained; a puzzle; a reference to our knowledge of this particularly distinctive species only as a cultivated plant.

Stems arborescent, to $0.5-4 \mathrm{~m}$ tall, 20-25 cm diam. at narrowest point; growing in soil; base not strongly swollen; bark thin and smooth. Leaves bright green, highly glossy, 200-290 cm long, flat (not keeled) in section (opposing leaflets inserted at $180^{\circ}$ on rachis), with 300-380 leaflets, tomentum shedding as leaf expands; rachis consistently terminated by paired leaflets; petiole $40-60 \mathrm{~cm}$ long (15-20\% of total leaf), glabrous, spinescent for $90-100 \%$ of length; basal leaflets not gradually reducing to spines, 220-230 mm long. Median leaflets simple, strongly discolorous, 300-340 mm long, 10-13 mm wide, inserted at $60-75^{\circ}$ to rachis, decurrent for 3-5 $\mathrm{mm}$, narrowed to $2.5-3 \mathrm{~mm}$ at base (to $20-30 \%$ of maximum width), $10-12 \mathrm{~mm}$ apart on rachis; section flat; margins flat or slightly recurved, not undulate; apex acute, not spinescent; midrib raised above, raised below, narrow. Cataphylls narrowly triangular, soft, pilose, 70-100 mm long. Pollen cones ovoid, green or cream, c. $34 \mathrm{~cm}$ long, c. $16 \mathrm{~cm}$ diam.; microsporophyll lamina firm, not dorsiventrally thickened, c. $80 \mathrm{~mm}$ long, c. $25 \mathrm{~mm}$ wide; fertile zone c. $29 \mathrm{~mm}$ long, level; apical spine prominent, gradually raised (spreading), c. $47 \mathrm{~mm}$ long. Megasporophylls 36-40 cm long, brown-tomentose, tomentum shedding; ovules 4-6, glabrous; lamina lanceolate, 220-240 mm long, 35-40 mm wide, deeply pectinate or shallowly pectinate, with 24-34 pungent lateral spines 16-25 mm long, 3-4 mm wide; apical spine distinct from lateral spines, 110-140 mm long, 6-7 mm wide at base. Seeds not observed. Fig. 3.

Historical notes: this singular and distinctive species was not recognised as new until 2001, in cultivation in Puerto Princessa City, and has remained undescribed until now.

Distinguishing features: it is distinguished from all other species in the region by the robust pollen cones with stout, spreading apical spines on microsporophylls and the open seed cones with long megasporophylls and very long attenuate megasporophyll apices with long slender lateral spines. The stout, spreading spines resemble those seen in C. circinalis and allies from peninsular India and C. pranburiensis from Thailand, but none of these species show the green colour in the male cone or the long-attenuate megasporophyll. It is however, grouped with these species in subsection Cycas on the basis of the shared microsporophyll character. 


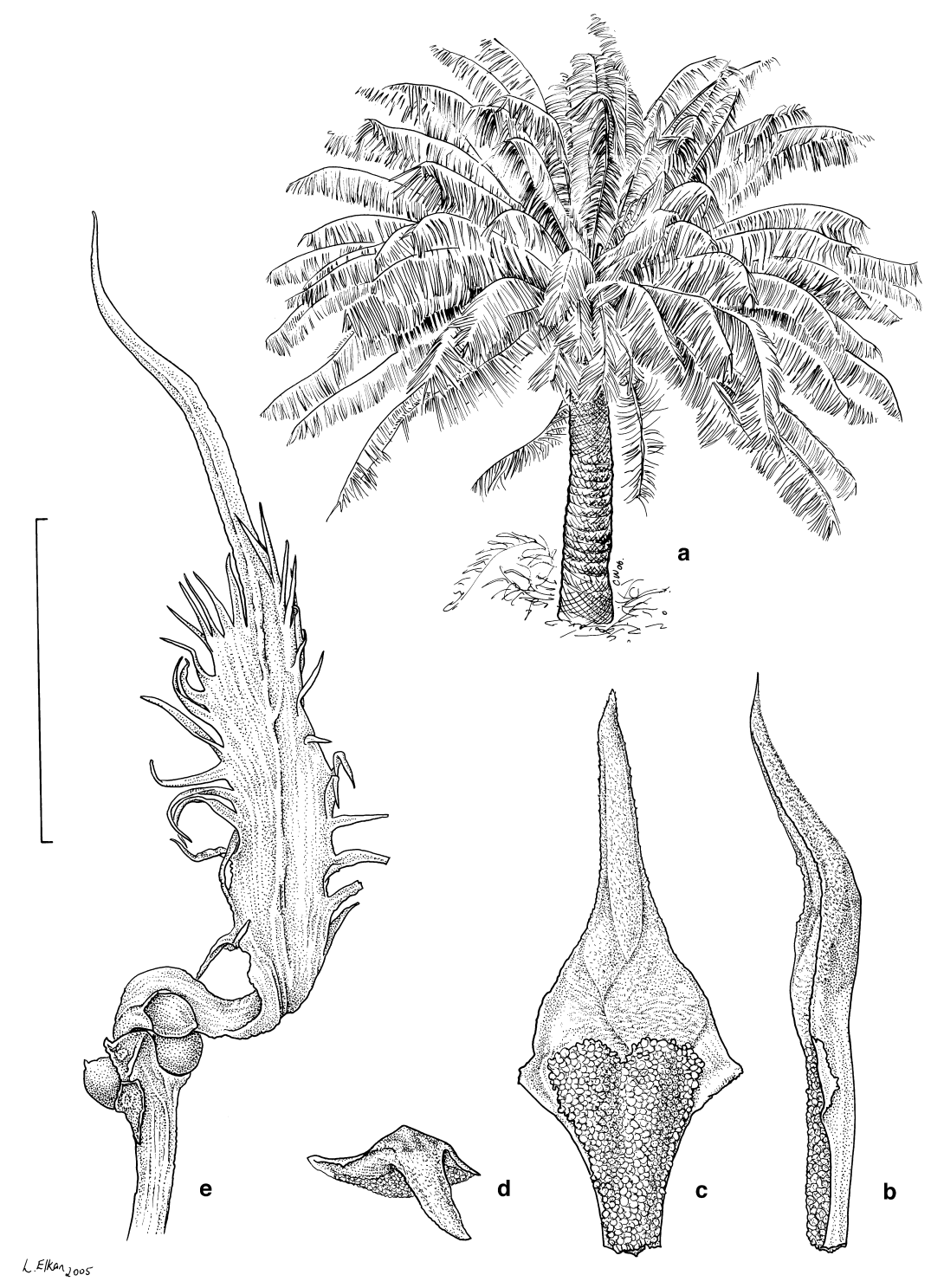

Fig. 3. Cycas aenigma. a, habit. b, c, d, male sporophyll. e, female sporophyll (a,b,c,d from K. Hill slides of Fernando E 1617, e from K. Hill slide of Fernando E 1618). Scale bar: a = no scale; b,c,d $=4 \mathrm{~cm} ; \mathrm{e}=6 \mathrm{~cm}$. 
Distribution and habitat: not known. This species is known only in cultivation in Puerto Princessa City on Palawan Island. It is not known if the plants originated on that island, but this seems probable.

Conservation status: Unknown. Recommended Ver 3.1:IUCN(2001) status would be DD.

Selected specimens: PHILIPPINES: Palawan: cult. Puerto Princessa city, Fernando 1618, 26 Jun 2001 (LBC).

5. Cycas riuminiana Porte ex Regel, Gartenflora 12: 16-17 (1863).

Cycas circinalis subsp. riuminiana (Porte ex Regel) J. Schust., Pflanzenr. 99: 68 (1932).

Type: ex horto bot. Petropolitano leg. ign. 62.10 (K). De Laubenfels and Adema (1998) designated this specimen as a lectotype, however the status of this specimen as original material is uncertain as there is no date on the sheet nor is it clear that Porte or Regel were the collectors (even though their names appear on the label). No type was cited in the original description. It is likely that Regel described the species from living plants in cultivation at the Imperial Botanic Garden in St Petersburg (see below). Given this uncertainty, it is probably better to consider this sheet as a neotype under the ICBN (Art. 9.8)

Cycas chamberlainii W.H.Brown \& Kienholz, Philipp. J. Sci. 26: 47-48, plate 1-2, fig. 1 (1925).

Cycas circinalis subsp. riuminiana var. curranii forma chamberlainii (W.H.Brown \& Kienholz) J. Schust., Pflanzenr. 99: 69 (1932).

Type: Philippines, Luzon, Pampanga Prov., Mt. Arayat, 23 May 1923, Brown \& Kienholz Bur. Sci. 42539 (iso NY, A, K, BM, L, P, US). The holotype at PNH is missing (or was destroyed in WW2).

Literature: Lemaire (1864), de Candolle (1868), Miquel (1868), Regel (1876), Foxworthy (1911, in part as C. circinalis), Merrill (1923, as C. rumphii), Amoroso (1986, in part as C. circinalis and also as C. chamberlainii), Zamora and Co (1986, as C. chamberlainii), de Laubenfels and Adema (1998).

Illustrations: Regel (1863), Lemaire (1864, plate 405), Foxworthy (1911 as C. circinalis, fig 1), Brown and Kienholz (1925, figs $1 \& 2$ ), Amoroso (1986, figs 5, 7-9, 27-30 as C. circinalis and figs 4, 4-16, 39-41 as C. chamberlainii).

Etymology: honouring - Riumin, president of the Moscow Horticultural Society.

Vernacular Ilocano-sawang (pref. to sauang); Tagalog—bayit (pref. to bait, vait), oliva (plant, pref. to oliba, uliba, uliva), pitógo (seed, pref. to bitogo, patubo, pitugo, potago), tamok (Merrill 1923, Zamora \& Co 1986, Amoroso 1986, Bonta \& Osborne 2007).

Stems arborescent, to $8 \mathrm{~m}$ tall, 5-10 cm diam. at narrowest point. Leaves bright green, highly glossy or semiglossy, 100-190 cm long, flat (not keeled) in section (opposing pinnae inserted at $180^{\circ}$ on rachis), with 120-240 leaflets, tomentum shedding as leaf expands; petiole $25-55 \mathrm{~cm}$ long (20-35\% of total leaf), glabrous, spinescent for 10 $100 \%$ of length; basal leaflets not gradually reducing to spines, $150-170 \mathrm{~mm}$ long. Median leaflets simple, weakly discolorous, $210-310 \mathrm{~mm}$ long, $7.5-13 \mathrm{~mm}$ wide, inserted at $45^{\circ}$ to rachis, decurrent for $6 \mathrm{~mm}$, narrowed to $2-5 \mathrm{~mm}$ at base (20-45\% of maximum width), 9-18 mm apart on rachis; section flat; margins slightly recurved; 
apex aristate, not spinescent; midrib raised above, raised below. Cataphylls linear, pungent, pilose. Pollen cones ovoid to fusiform, orange or brown, c. $20 \mathrm{~cm}$ long, c. $6 \mathrm{~cm}$ diam.; microsporophyll lamina firm, not dorsiventrally thickened, c. $23 \mathrm{~mm}$ long, c. $17 \mathrm{~mm}$ wide, fertile zone c. $18 \mathrm{~mm}$ long, sterile apex c. $5 \mathrm{~mm}$ long, level, apical spine prominent, sharply upturned, c. $11 \mathrm{~mm}$ long. Megasporophylls $15-24 \mathrm{~cm}$ long, browntomentose; ovules 4-10, glabrous; lamina lanceolate to elliptical, 43-65 $\mathrm{mm}$ long, 15-30 mm wide, shallowly pectinate; with 10-30 pungent lateral spines 2-13 mm long, 1-1.5 mm wide; apical spine distinct from lateral spines, 15-32 $\mathrm{mm}$ long, 4-6 mm wide. Seeds ovoid, 31-41 mm long, 24-26 mm wide; sarcotesta yellow, $3 \mathrm{~mm}$ thick, fibrous layer absent; sclerotesta smooth; thin, spongy endotesta present.

Historical notes: described in 1863 by German-born botanist Eduard Auguste von Regel (1815-1892), Scientific Director and later Director of the Imperial Botanic Garden in St Petersburg, 1855-1892. No type was cited. Plants were imported from Manila by Porte and sold by the Moscow Horticultural Society through the Belgian horticultural trading firm of Verschaffelt. In 1864 Lemaire published a description with a colour plate in L'Illustration Horticole. This species was listed by De Candolle (1868) as "species minus notae" (species without distinction), De Candolle also stated that there was no obvious distinction from C. circinalis or C. rumphii. Miquel (1868) repeated De Candolle's descriptive notes. Foxworthy in 1911 cited numerous specimens under C. circinalis, some of which could possibly represent $C$. riuminiana. This name was ignored by Merrill until listed as a synonym of C. rumphii in 1923, although Merrill had noted small-fruited specimens from Mindoro and the Mt Mariveles and Batangas districts of Luzon. The name was ignored by Zamora and Co (1986) and Amoroso (1986); this taxon was treated as C. circinalis in both publications.

This species was then described as C. chamberlainii in 1925 by William H. Brown, Director of the Philippine Bureau of Science, and Raymond Kienholz, Professor of Botany at the University of the Philippines, who also collected the type specimens. The authors noted that it has been known for some time that ... there was a slender mountain form with small seeds which was possibly, or probably, a distinct species', after Merrill (1923). They made no reference to C. riuminiana, and may have been unaware of this name.

Schuster (1932) treated C. riuminiana as a form of C. circinalis, and segregated C. chamberlainii as $C$. circinalis subsp. riuminiana var. curranii forma chamberlainii.

Both Amoroso (1986) and Zamora and Co (1986) accepted C. chamberlainii as a distinct species, under a restricted circumscription including only the Mt Arayat collections, treating other material here regarded as conspecific as $C$. circinalis.

De Laubenfels and Adema (1998) treated C. chamberlainii as a synonym of C. riuminiana, and included material now known as C. falcata from Sulawesi, Indonesia, in a wide and unclear circumscription.

Distinguishing features: distinguished in the Philippines by the narrow leaflets with a midrib strongly raised above, long sharp cataphylls, and megasporophylls with up to 30 lateral spines $2-13 \mathrm{~mm}$ long and a distinct slender apical spine up to $32 \mathrm{~mm}$ long.

Distribution and habitat: an inland species of forested areas on ridges and mountains, in closed mixed evergreen forests usually on steep slopes. Abundant on northern Luzon, south at least to Batangas (Fig. 1). Seeds in wide circulation in horticultural circles in the 1990's as "Philippines small seed" apparently belong with this species. These were said 
to have come from Mindoro, but this has not been confirmed. The mature plants now in cultivation appear to differ slightly from C. riuminiana from Luzon (They are more robust with larger seeds), but would seem to fit within an overall range of variation. More field study is obviously required on Mindoro, but this is at present not possible.

Conservation status: although $C$. chamberlainii was reported to have been destroyed in the original habitat by clearing for agriculture and given a 1997 IUCN Red List of Threatened Plants category V, this species actually remains in abundance in healthy populations on Mt Arayat, as well as in many other montane forest areas. Ver 3.1:IUCN (2001) status is DD (Donaldson 2003). Recommended status would be LC.

Selected specimens: PHILIPPINES: Luzon: Isabela Prov., Mt Dipalayag, Sierra Madre Range, 1657'N 12214'E, Co 3342, 27 Feb 1991 (A, PNH, L); Pampanga Prov., Arayat, Loher 4844, Jun 1896 (K, L); Pampanga Prov., Mt Arayat, McGregor BS 42080, Mar 1923 (K, L); Pampanga Prov., Mt Arayat, southern ecotrail, Fernando 1608, 19 Jun 2001 (LBC); Bataan Prov., Lamas, Curran FB 7513, 19 Apr 1909 (K); Bataan Prov., Lamao River, Mt Mariveles, hill forest, $2000 \mathrm{ft}$, Merrill 3257, Oct 1908 (BM, K, NY, P); Bataan Prov., Mt Mariveles, Lamao River, Meyer FB 2577 (K, NY); Bataan Prov., Lamao River, Whitford 1235, May 1905 (K, NY); Batanes Prov., Batan Island, Ramos BS 80613, Jun-Jul 1930 (K, NY); Batangas Prov., Bugaan East, Laurel, cult. in village, coll. on Mt Tagaytay, Fernando 1604, 16 Jun 2001 (LBC); Batangas Prov., Ramos BS 22391, Jul-Aug 1914 (A, BM, K, L, NSW, NY); Cagayan, fide Amoroso (1986), no voucher; Cavite, fide Amoroso (1986), no voucher; Laguna, fide Amoroso (1986), no voucher. Cult.: Merrill Sp. Blancoanae 855, Mar 1915 (A, BM, BO, K, L, NSW, NY); cult. Kew, 19 Jan 1897 (K); Manilla \& vicinity, Merrill 9795, Dec 1914 (A, BM, BO, L, NY, P); ex horto Bot. Petropolitano, leg. ign. 70.7 (LE).

\section{Cycas vespertilio A.J.Lindstrom \& K.D.Hill, sp. nov.}

Inter species philippinenses combinatione characterum sequentium distinguitur: foliola lata, megasporophylla elongata ad apicem alata.

Type: Philippines: Panay: Iloilo, Barotac Viejo, Barangay Lipata, Sitio Nagpana, Mt. Opao, Lindstrom AL 06/008, 4 Mar 2006 (holotype LBC; iso NSW, BKF).

Etymology: the specific epithet is from the Latin vespertilio, a bat, from vesper (evening), literally 'the little one of the evening', in reference to the wing-like extensions on the megasporophyll apex.

Stems arborescent, to 1-3 $\mathrm{m}$ tall, 12-20 cm diam. at narrowest point; base not strongly swollen; bark thin with persistent cataphylls. Leaves bright green, glossy, $128-210 \mathrm{~cm}$ long, flat (not keeled) in section, with 93-117 leaflets tomentum shedding as leaf expands; petiole $46-52 \mathrm{~cm}$ long, shedding brown tomentum, spinescent for $90-100 \%$ of length; basal leaflets not gradually reducing to spines, 180-200 mm long. Median leaflets simple, not discolorous, keeled in transect, 270-290 mm long, 10-13 mm wide, narrowed to 2-3 $\mathrm{mm}$ at base, $10-14 \mathrm{~mm}$ apart on rachis; section flat; margins edged, or slightly recurved, undulate; apex acute, not spinescent; midrib raised above, raised below, narrow. Cataphylls broadly triangular, stiff, pilose, 55-60 mm long. Pollen cones not seen. Megasporophylls $17-19 \mathrm{~cm}$ long, cream-tomentose, tomentum not shedding; ovules 6-7, glabrous; lamina rhomboid, winged, 160-180 mm long, 32-35 mm wide, lateral spines 2, broad, flattened \& wing-like; apical spine distinct from lateral spines, 35-38 mm long, 3-5 mm wide at base. Seeds obovoid, c.36 mm long, $27 \mathrm{~mm}$ wide; fibrous layer absent; sclerotesta smooth; spongy endotesta present, thin (see discussion under C. zambalensis). Fig. 4. 


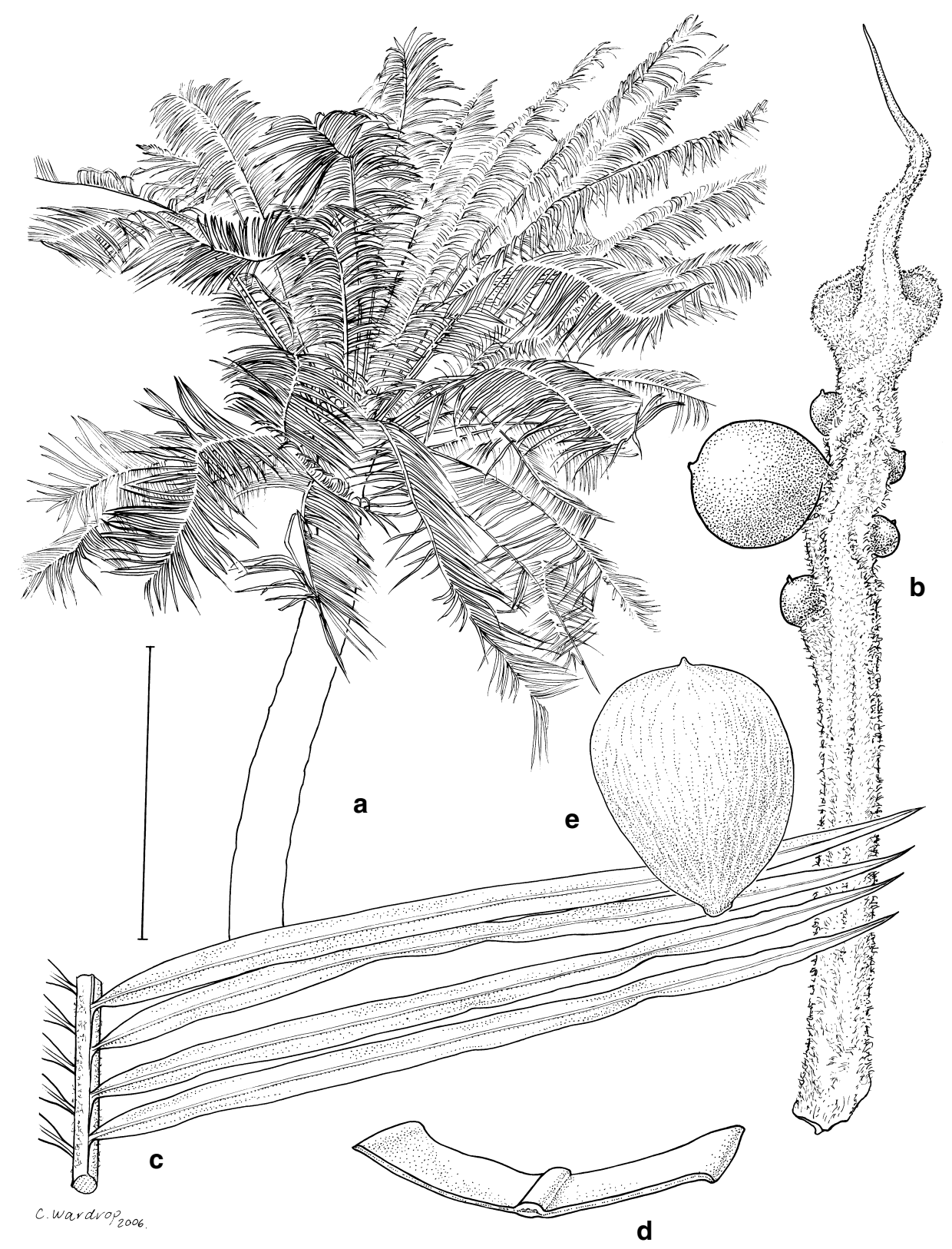

Fig. 4. Cycas vespertilio. a, sketch of habit (from A. Lindstrom slide). b, female sporophyll. c, part of leaf. d, cross-section of leaflet. (b,c,d,from Lindstrom AL 06/008), e, seed (from NSW 638085). Scale bar: $\mathrm{a}=$ no scale, $\mathrm{b}=4 \mathrm{~cm}, \mathrm{c}=10 \mathrm{~cm}, \mathrm{~d}=1 \mathrm{~cm}, \mathrm{e}=4 \mathrm{~cm}$. 
Historical notes: although first collected in 1928 by Edaño, this taxon was not recognised as a distinct species until 2006.

Distinguishing features: the megasporophylls with two lateral wings distinguish this from all other Philippine cycads. The seeds are obovoid and somewhat dorsiventrally flattened.

Distribution and habitat: Philippines, hill forests of Panay, Negros, Cebu, Leyte, Samar and southernmost Luzon (Fig. 1). Seasonally deciduous forest with Pterocarpus indicus and bamboo. Yellow clay overlying sandstone or volcanic cinders. Southwest facing slopes sometimes in full sun but more often in shaded situations.

Conservation status: taking the wide distribution range in account the species is not under immediate threat. However, deforestation on Negros, Panay and Leyte is already extreme and little habitat is left. Recommended Ver 3.1:IUCN(2001) status would be NT.

Selected specimens: PHILIPPINES: Leyte: Gigantangan (? Hingatungan), Kondo \& Edaño PNH 36862, 30 Mar 1957 (L). Luzon: Panagan River, Camarines Sur, Edaño BS 76373, Dec 1928 (BO, G, NY). Marinduque: Torrijos, Bonliw, Talisay, Fernando 606, 7 Aug 1996 (LBC 7181, K?). Mindoro: Mt Yagaw, E slope, Conklin PNH 18682, 27 Jul 1953 (A, L); Mt Yagaw, E slope, edge of mangrove swamp, Conklin PNH 37914, 12 Apr 1958 (A, L). Negros: Negros Oriental, cult. in house, not of confirmed origin but said to have been collected from the extreme south of the island, Lindstrom AL06/006, 3 Mar 2006 (NSW). Panay: Nagpana, Barotac Viejo, Iloilo, $11^{\circ} 02^{\prime} \mathrm{N} 122^{\circ} 15^{\prime} \mathrm{E}$, Madulid 7232, 15 Nov 1989 (A). Cult.: Pasay City, Mendoza PNH 37074, 2 Jul 1956 (BM, L).

\section{Cycas lacrimans A.J.Lindstrom \& K.D.Hill, sp. nov.}

Inter species philippinenses combinatione characterum sequentium distinguitur: foliola demissa; megasporophylla elongata spinis lateralibus reductis; fructus non spongiosus.

Type: Philippines: Mindanao: Davao, Mati, Ramos \& Edaño BS 48953, Mar-Apr 1927 (holo NY, iso BM, BO, P).

Etymology: the specific epithet is from the Latin lacrimans, crying, in reference to the drooping or weeping habit of the leaves.

Stems arborescent, to 1-2 $\mathrm{m}$ tall, 18-20 cm diam. at narrowest point; base not strongly swollen; bark thin with persistent cataphylls. Leaves glossy green, 168-200 cm long, flat (not keeled) in section, with 76-85 leaflets; petiole 45-50 cm long, lacking tomentum, spinescent for $90-100 \%$ of length with needle-like stout $6 \mathrm{~mm}$ long spines; basal leaflets not gradually reducing to spines, 170-190 mm long. Median leaflets simple, discolorous underneath, 280-320 $\mathrm{mm}$ long, 7-13 mm wide, narrowed to 2-3 $\mathrm{mm}$ at base, 12-14 mm apart on rachis; section recurved; margins folded, not undulate; apex acute, not spinescent; midrib sunken above, raised below. Cataphylls broadly triangular, stiff, pilose, 55-60 mm long. Pollen cones ovoid, light brown, c. $42 \mathrm{~cm}$ long, c. $16 \mathrm{~cm}$ diam.; microsporophyll lamina firm, not dorsiventrally thickened, c. $34 \mathrm{~mm}$ long, $19 \mathrm{~mm}$ wide, fertile zone 34-38 mm long, sterile apex 1-2 mm long, level; apical spine very slender, 12-17 mm long. Megasporophylls c. $37 \mathrm{~cm}$ long, cream-tomentose, tomentum not shedding; ovules 4-6, glabrous; lamina triangular, c. $55 \mathrm{~mm}$ long, c. $20 \mathrm{~mm}$ wide, lateral spines shallowly pectinate; with 15-24 pungent lateral spines 3-8 mm long, 1-2 mm wide; apical spine distinct from lateral spines, $35-38 \mathrm{~mm}$ long, 3-5 mm wide at base. Seeds oblong, c. $40 \mathrm{~mm}$ long, c. $20 \mathrm{~mm}$ wide; sclerotesta smooth; spongy endotesta absent. Fig. 5. 


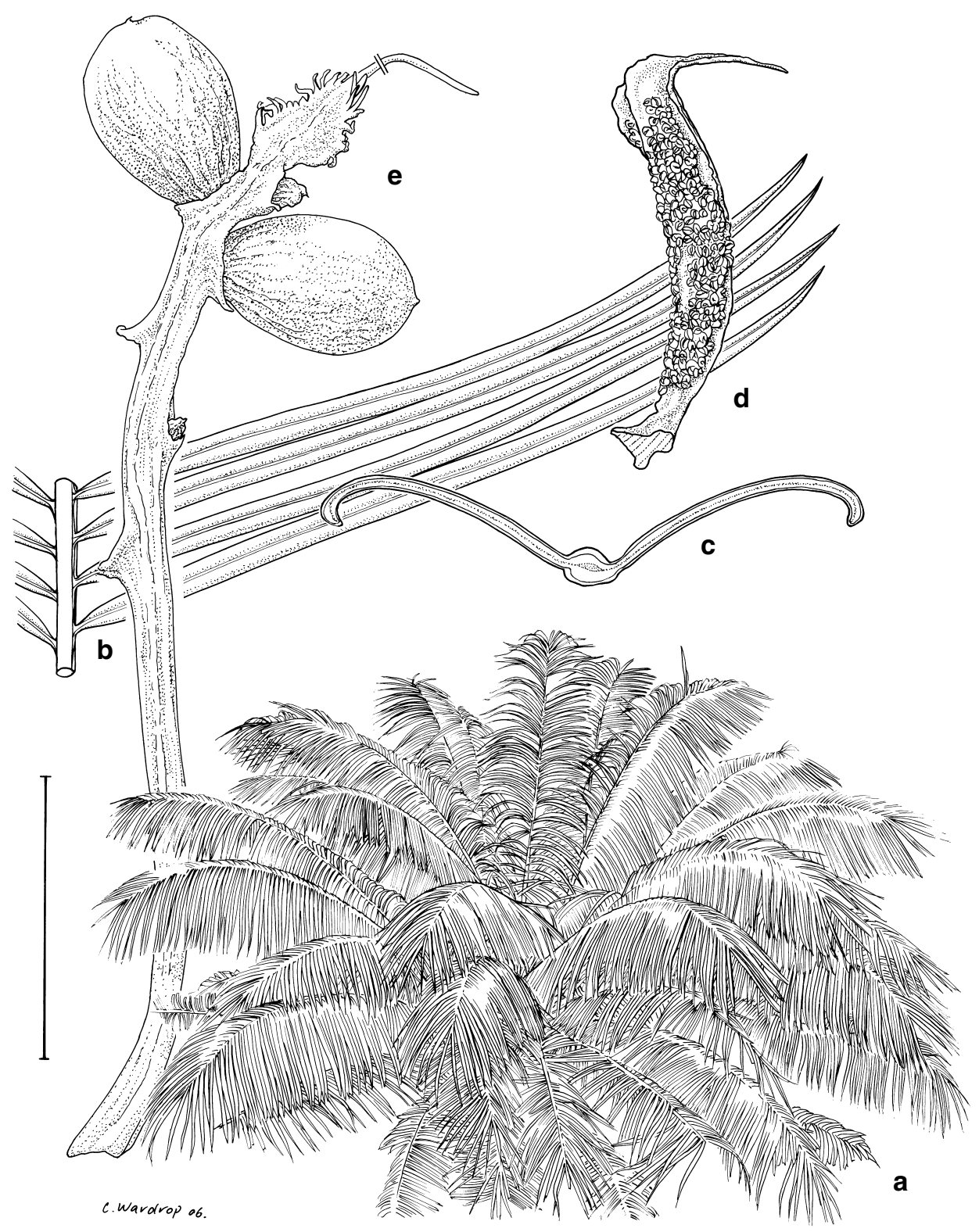

Fig. 5. Cycas lacrimans. a, sketch of habit (from A. Lindstrom slide). b, part of leaf. c, crosssection of leaflet (from Lindstrom AL 06/004). d, male sporophyll (from NY digital image of NY sheet of Ramos \& Edano 48953). e, female sporophyll (reconstructed from Lindstrom AL 07/018). Scale bar: $\mathrm{a}=$ no scale, $\mathrm{b}=10 \mathrm{~cm}, \mathrm{c}=0.6 \mathrm{~cm}, \mathrm{~d}=6 \mathrm{~cm}, \mathrm{e}=3 \mathrm{~cm}$. 
Historical notes: although first collected in 1927 by Ramos \& Edaño, this taxon was not recognised as a distinct species until 2006.

Distinguishing features: the long megasporophylls with reduced lateral spines, the seeds with no spongy endotesta and the lax, drooping leaflets distinguish this from all other Philippine species.

Distribution and habitat: Philippines, known at present only from hill forests of eastern Mindanao (Fig. 1). Serpentine soil.

Conservation status: if restricted to this small area the species is in need of urgent protection in situ. Deforestation and other habitat destruction is extreme. Recommended Ver 3.1:IUCN(2001) status would be EN.

Selected specimens: PHILIPPINES: Mindanao: Davao Oriental, Municipality of San Isidro, cult. in house at the foothill of Mt. Galintan, planted 1960's, said to come from nearby now destroyed seaside, Lindstrom AL 06/004, 29 Feb 2006 (NSW); Davao Oriental, Barangay Sto. Rosario, Mati district, Mt.Hamiguitan, Maeudlong Forest Reserve, Lindstrom AL 07/018, 12 Mar 2007 (NSW); Davao, Mt Galintan, Ramos \& Edaño BS 48912, Jun 1927 (NY); Bukidnon, fide Amoroso (1986) as C. circinalis, no voucher; Surigao, fide Amoroso (1986) as C. circinalis, no voucher; Zamboanga, fide Amoroso (1986) as C. circinalis, no voucher.

8. Cycas zambalensis Madulid \& Agoo, Blumea 50(3): 519-522 (2005).

Type: Philippines, Zambales, San Antonio, Madulid \& Agoo PNH 173358, 2005 (holo $\mathrm{PNH}$.

Illustrations: Madulid \& Agoo (2005).

Etymology: the specific epithet refers to the name of the locality, Zambales, where this population is located.

Stems arborescent, to $3 \mathrm{~m}$ tall, $15 \mathrm{~cm}$ diam. at narrowest point; base not strongly swollen. Leaves dark green, semiglossy, 100-190 cm long, keeled in section (opposing leaflets inserted at less than $180^{\circ}$ on rachis), with 99-260 leaflets, with brownish tomentum not shedding as leaf expands; petiole 30-44 cm long ( $25-33 \%$ of total leaf), tomentose, spinescent for $60-80 \%$ of length; basal leaflets not gradually reducing to spines, $130 \mathrm{~mm}$ long. Median leaflets simple, 120-260 mm long, 5-8 mm wide, 5-10 $\mathrm{mm}$ apart on rachis; narrowed to $2.5 \mathrm{~mm}$ at base, margin straight; midrib flat above, raised below. Cataphylls narrowly triangular, needle-like, $60-70 \mathrm{~mm}$ long, stiff, pilose. Pollen cones brownish orange, ovoid to long ovoid, tapering, to $36 \mathrm{~cm}$ long, to 18 cm diam.; microsporophyll lamina firm, not dorsiventrally thickened, 30-50 mm long, 10-30 mm wide; apical spine prominent, sharply upturned or gradually raised, 5-25 mm long. Megasporophylls 22-35 cm long, densely brown-tomentose, tomentum persistent; ovules 4-6, glabrous; lamina ovate or lanceolate, 70-80 mm long, 40-50 mm wide, shallowly pectinate, with 20-34 pungent lateral spines 6-14 mm long, c. $1 \mathrm{~mm}$ wide; apical spine distinct from lateral spines, 30-35 mm long, 5-7 mm wide. Seeds flattenedovoid, to $43 \mathrm{~mm}$ long, to $36 \mathrm{~mm}$ wide; sarcotesta yellow, not pruinose; fibrous layer absent; sclerotesta smooth; spongy endotesta present, thin.

Historical notes: this endemic species was discovered and described in 2005.

Distinguishing features: the species is easily distinguished from the other Philippine Cycas in having tomentose pinnae and rachis. The pinnae of C. zambalensis are also rigid and stiff, and the leaves are keeled. Based on these characteristics, the young 
individuals of $C$. zambalensis resemble C. revoluta, a common ornamental plant in the country.

Cycas zambalensis is very similar to C. riuminiana (syn: C. chamberlainii), also found in the Philippines, in having long petioles (at least $25 \mathrm{~cm}$ ) and very woolly megasporophylls. The species differs from C. riuminiana in having narrower pinnae, longer than wide sterile apex of the megasporophyll, larger apical spine on the megasporophyll, persistently lanate megasporophylls, and tomentose leaflets and rachis. The hairs persist even in dried specimens. The pinnae are short, rigid and stiff, and the leaves are keeled. The seeds are slightly flattened.

A spongy endotesta was observed in one cultivated individual (Fernando 1605). This might represent present or past hybridization with subsection Rumphiae either in the ancestry of this group or this plant.

Distribution and habitat: San Antonio, Kawag, Bucao, Zambales, NW Luzon. Endemic (Fig. 1).

Cycas zambalensis is restricted to the ultrabasic grassy hills of Zambales, a distinct biogeographic region in the western part of Luzon Island. The plants are usually scattered wide apart on the hillsides and do not form distinct groups. Plants grow fully exposed to the sun and strong wind near the sea.

The population dominates the seasonally dry, hilly grasslands of the Zambales Peninsula, which is distinct from the lowland evergreen rain forests of the BataanZambales mountain range. The soils in the area are ultramafic and rich in chromite deposits. There are two pronounced seasons in the province: the dry season which is from November to April and the wet season for the rest of the year. Maximum rainfall occurs from June to September which coincides with the southwest monsoon.

Conservation Status: the very limited distribution of C. zambalensis, changing land use of the habitat of the species, and increasing pressure from collection for the horticultural trade are serious threats to the species. It is considered a critically endangered species. The effect of occasional fire to the population has yet to be evaluated. Recommended Ver 3.1:IUCN(2001) status would be CR (Madulid \& Agooo 2005).

Selected specimens: PHILIPPINES: Luzon: Bataan Prov., Subic Bay Freeport zone, cult. in Summit Hotel complex, coll. just outside freeport zone, Fernando E 1605, 1606, 18 Jun 2001 (LBC); Zambales, San Antonio district, Barangay Punakit, on the slopes of Mt.Anawangan, GPS: N 1455.293'E 12004.239' Alt. 300 m, Lindstrom AL 06/013, AL 06/014, 8 Mar 2006 (NSW); cultivated in the town of San Antonio, along the way to the beach, Lindstrom AL 06/015, 8 Mar 2006 (NSW); Bataan, Subic bay district, cultivated outside the restaurant at Crown Peak Hotel within former US Navy base, Lindstrom AL 06/016, AL 06/017, 8 Mar 2006 (NSW).

Cycas subsection Rumphiae K.D.Hill, Austral. Syst. Bot. 7: 548 (1994).

Type: C. rumphii Miq., Bull. Sci. Phys. Nat. Neerl. 2: 45 (1839).

This subsection is uniquely defined by the presence of a layer of spongy tissue within the seed. Microsporophylls are also distinctive, being more or less dorsiventrally thickened, with short or vestigial, sharply upturned apical spines. Another potentially synapomorphic character defining this group is the 2-year seed maturation period, although this has been confirmed only for C. seemannii, C. thouarsii and C. bougainvilleana. All other species of Cycas for which data is available have a seed maturation period of less than one year. 
Distribution is very wide, extending from Africa to Fiji and Tonga, and from New Guinea north to southern coastal Indochina. Two species occur in The Philippines.

The spongy endotesta causes seeds to be buoyant, and has been proposed as a dispersal mechanism (Dehgan \& Yuen 1983). This dispersal mechanism has been interpreted as a cause of the taxonomic complexity of this group, with successive colonisation events producing the high local variability in some populations and the very different forms sometimes occurring in close proximity (Hill 1994, Fosberg \& Sachet 1975).

9. Cycas edentata de Laub., in De Laub. \& Adema, Blumea 43: 372 (1998).

Type: Philippines, Sulu Archipelago, Mt Cabucan, Kondo \& Edaño 38877, Jan-Feb 1957 (holo L; iso A, BM).

Cycas litoralis K.D.Hill, Brittonia 51(1): 70, fig. 11 (1999).

Type: Thailand. Ao Manao Naol, Narathiwat, K.D. Hill 4627 \& Poonsak Vatcharakorn, 20 Apr 1994 (holo NSW; iso BKF, K, L, PE)

Cycas circinalis subsp. riuminiana var. curranii forma maritima J. Schust., Pflanzenr. 99: 69 (1932).

Lectotype (here designated): Philippines, Calusa Island, 29 July 1912, Fenix 15660 (lecto $\mathrm{K}$, isolecto $\mathrm{L}$ ). Schuster cited a number of specimens in his protologue. The specimen chosen as lectotype is one that is stated as being a coastal collection.

Literature: Kurz (1877, as C. rumphii), Foxworthy (1911, as C. circinalis), Merrill (1912, as C. circinalis), Merrill (1917, as C. rumphii), Merrill (1918. as C. circinalis), Merrill (1921, as C. circinalis), Merrill (1923, as C. rumphii), Backer (1925, as C. rumphii p.p.), Ridley (1925, as C. rumphii), Leandri (1931, as C. rumphii), Ochse (1931, as C. rumphii p.p.), Schuster (1932, as C. rumphii p.p.), Kanehira (1938, as C. rumphii p.p.), Ho and Duong (1960, as C. rumphii), Suvatabandhu (1961, as C. rumphii), Backer and Bakhuizen van den Brink (1963 as C. rumphii p.p.), Smitinand (1971 as C. rumphii), Smitinand (1972 as C. rumphii), Zamora and Co (1979 as C. circinalis in part), Amoroso (1986 as C. rumphii), Hill and Yang (1999 as C. litoralis).

Illustrations: Ridley (1925), Schuster (1932 as C. rumphii p.p.), Smitinand (1971), Cheng et al. (1975, as C. rumphii), Amoroso (1986, as C. rumphii), de Laubenfels \& Adema (1998), Hill and Yang (1999, as C. litoralis)

Etymology: from the Latin dentata, toothed, with the Latin prefix $e^{-}$, without, in reference to the megasporophyll apices.

Vernacular: Malay - kwale pahang (woods on sea shore), Thai - prong thale (sea cycad), Ilocano - sauang, sawang, Tagalog - bait, bayit, pitógo (preferred to potago, patubo, pitugo or bitogo), Spanish - oliba, oliva (preferred), uliba, uliva, unidentified lang. - vait (Hill \& Vatcharakorn 1998, Ridley 1893, Amoroso 1986, Schuster 1932, Zamora \& Co 1986, Bonta \& Osborne 2007).

Stems arborescent, to $10 \mathrm{~m}$ tall, to $20 \mathrm{~cm}$ diam. at narrowest point, numerous leaves in crown. Leaves bright to deep green, highly glossy, 130-230 cm long, flat (not keeled) in section (opposing leaflets inserted at $180^{\circ}$ on rachis), with 100-200 leaflets, tomentum shedding as leaf expands; rachis consistently terminated by paired leaflets; petiole 30 $90 \mathrm{~cm}$ long (20-50\% of total leaf), glabrous, spinescent for $5-100 \%$ of length; basal leaflets not gradually reducing to spines, 120-280 mm long. Median leaflets simple, 
strongly discolorous, $220-370 \mathrm{~mm}$ long, $11-19 \mathrm{~mm}$ wide, inserted at $45-80^{\circ}$ to rachis, decurrent for 5-13 $\mathrm{mm}$, narrowed to $5-8 \mathrm{~mm}$ at base (to $35-50 \%$ of maximum width), 12-35 mm apart on rachis; section flat; margins slightly recurved, not undulate; apex acute, not spinescent; midrib flat or raised above, raised below, wide. Cataphylls narrowly triangular, soft, pilose, $40-70 \mathrm{~mm}$ long. Pollen cones narrowly ovoid or fusiform, orange, 35-60 cm long, 11-17 cm diam; microsporophyll lamina firm, not dorsiventrally thickened, 35-44 mm long, 12-23 mm wide, fertile zone 30-35 $\mathrm{mm}$ long, sterile apex 5-6 mm long, level to slightly deflexed; apical spine prominent, sharply upturned, 9-24 mm long. Seed cones open at pollination, open at seed set. Megasporophylls 24-50 cm long, white-, yellow-tomentose or brown-tomentose, tomentum persistent; ovules 2-8, glabrous; lamina lanceolate, 43-120 mm long, 20-40 mm wide, lateral spines short or indistinct; apical spine distinct from lateral spines, $14-40 \mathrm{~mm}$ long, 4-12 mm wide at base. Seeds flattened-ovoid, 45-66 mm long, 35-50 mm wide; sarcotesta orange-brown, not pruinose, 3-5 mm thick; fibrous layer absent; sclerotesta smooth; spongy endotesta present.

Historical notes: known since the earliest accounts of the Philippine flora, this species was only described by de Laubenfels and Adema in 1998. This taxon has been included in C. rumphii by numerous authors, starting with Kurz in (1877), with the exception of Foxworthy (1911) and Merrill $(1912,1918,1921)$ as C. circinalis. Schuster (1932) described it as C. circinalis subsp. riuminiana var. curranii forma maritima. Hill recognised this as a distict taxon in 1995 (Hill 1998) and formally described the taxon as C. litoralis in April 1999. De Laubenfels had already described this taxon as C. edentata, published in 1998 but with a confused circumscription that included C. glauca, C. rumphii and others.

Distinguishing features: very highly glossy leaves; long spines on microsporophyll tips, no or rudimentary teeth on megasporophyll tips, spongy endotesta in seed.

Distribution and habitat: usually in littoral forests or on beachfronts, widespread and locally common in much of south-east Asia (Fig. 1).

Conservation status: this species occurs in coastal sites that have experienced severe pressures from population increase and development. This habitat is also coming under increasing pressure for aquaculture sites. Although probably not immediately threatened, it is potentially vulnerable in the longer term. Ver 3.1:IUCN(2001) status is DD (Donaldson 2003) for The Philippines. Recommended status would be NT.

Selected specimens: PHILIPPINES: Balabac: Bancalan Is, Weber s.n., 7.1916 (A). Basilan: Klemme FB 15219, Aug 1910 (K, L); Basilan, Hutchinson FB 3441, 10 Dec 1905 (K). Cagayan Is: Calusa Is., Fenix BS 15660, 29 Jul 1912 (BM, K, L). Cebu: Lapu Lapu City, Olango Island, Madulid et al. PPI 7622, 20 Mar 1993 (BO). Masbate: Hamoraon Island, Kondo \& Edano PNH 36862, 30 Mar 1957 (L). Mindanao: Prov. Davao, Santa Cruz, Williams 2890, 17 Jun 1905 (NY); Prov. Davao, between Digas and Santa Cruz, Williams 3058, 29 Jun 1905 (GRAY, K, NY); Davao Oriental, Mati district, Mayo Bay, cult. at the House of F.G.R.Dahican (Mayor), Planted 1960's, said to come from nearby now destroyed seaside, Lindstrom AL 06/001, AL 06/002, 29 Feb 2006 (NSW); Caldera, Wilkes exped. s.n., 1832-1842 (GRAY);Zamboanga Prov., Merrill 11638, Sep 1922 (A, BO). Mindoro: Bongabon and Pinamalayan, Maliwang 253, 5 Feb-5 Apr 1941 (A). Negros: Negros Oriental, Dumaguete district, Secondary seriously destroyed seaside forest, Lindstrom AL 06/005, 3 Mar 2006 (NSW). Panay: Iloilo, fide Amoroso (1986), no voucher. Palawan: Culion, Alava Island, Halsey Harbour, Fernando 1609, 1610, 22 Jun 2001 (LBC); cult. Puerto Princessa city, coll. from coastal forest near San Vicente, Fernando 1616, 26 Jun 2001 (LBC). 


\section{Cycas nitida K.D.Hill \& A.Lindstrom, sp. nov.}

Inter species philippinensis combinatione characterum sequentium distinguitur: folia nitida; strobili masculi parvi; microsporophylla apice spinis magnis longioribus robustisque; megasporophylla elongata spinis lateralibus prominentibus; fructus non spongiosus.

Type: Philippines, Luzon, seeds from Rapu Rapu Is., E. of Luzon, plant (female) cult. Sydney Botanic Gardens, 2006 (holo NSW 728768).

Etymology: from the Latin nitida, shining, in reference to the extremely glossy leaves.

Stems arborescent. Leaves deep green, highly glossy, 150-180 cm long, flat (not keeled) in section (opposing pinnae inserted at $180^{\circ}$ on rachis), with 160-200 leaflets tomentum shedding as leaf expands; petiole $30-60 \mathrm{~cm}$ long, glabrous, spinescent for $50 \%$ of length; basal leaflets not gradually reducing to spines, $270 \mathrm{~mm}$ long. Median leaflets simple, strongly discolorous, $270-370 \mathrm{~mm}$ long, $14-18 \mathrm{~mm}$ wide, $12-17 \mathrm{~mm}$ apart on rachis; section flat; margins slightly recurved; apex acute, not spinescent; midrib raised above, raised below. Cataphylls narrowly triangular, soft, pilose. Pollen cones fusiform, orange, $16 \mathrm{~cm}$ long, $4.5 \mathrm{~cm}$ diam.; microsporophyll lamina firm, not dorsiventrally thickened, 37-44 mm long, 12-23 mm wide; apical spine prominent, sharply upturned, 13-23 mm long. Megasporophylls 24-34 cm long, brown-tomentose; ovules 2-4, glabrous; lamina lanceolate, 43-60 mm long, 20-30 mm wide, distinctly dentate; with 8-16 lateral spines, pungent, 3-5 mm long; apical spine distinct from lateral spines, 14-20 mm long. Seeds flattened-ovoid, 55-66 mm long, 45-50 mm wide; sarcotesta orange-brown; fibrous layer absent; sclerotesta smooth; spongy endotesta present. Fig. 6.

Distinguishing features: very highly glossy leaves; small male cones, long spines on microsporophyll tips, distinct teeth on megasporophyll tips, spongy endotesta in seed.

Distribution and habitat: Philippines only, usually in littoral forests on the north and east of Luzon island (Fig. 1).

Conservation status: this species occurs in coastal sites that have experienced severe pressures from population increase and development. This habitat is also coming under increasing pressure for aquaculture sites. Although probably not immediately threatened, it is potentially vulnerable in the longer term. Recommended Ver 3.1:IUCN(2001) status would be NT.

Selected specimens: PHILIPPINES: Luzon: Alabat Island, Ramos \& Edaño BS 48310, Sep-Oct 1926 (LE, NY); Tabayas Prov., Curran 10319, 4.1908 (NY); Prov. Dalupir Is, Babuyan group, $19^{\circ} 10^{\prime} \mathrm{N} 121^{\circ} 15^{\prime} \mathrm{E}$, Bartlett 15158, 31 Oct-5 Nov 1935 (A). Polillo: fide Amoroso (1986), no voucher. Cult.: male and female plants, S.J. Walkley, Burpengary, seeds from Rapu Rapu Is., E. of Luzon, Walkley s.n. (NSW 728765, 728767, 731813); male plant, Sydney Botanic Gardens (NSW 930437, 619428) 


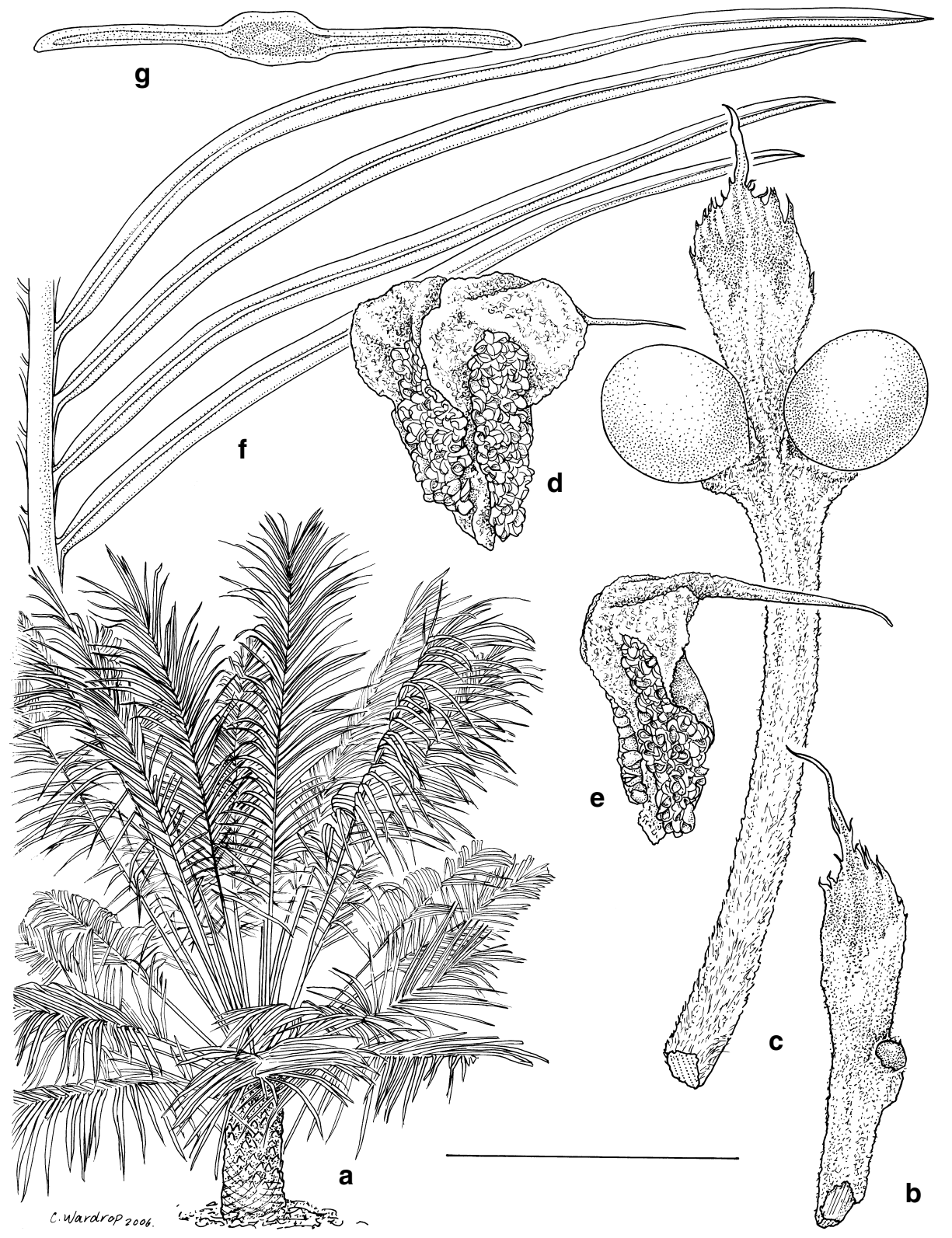

Fig. 6. Cycas nitida. a, sketch of habit (from digital image of S.J. Walkley cult. plant). b, immature female sporophyll (from NSW 728765). c, mature sporophyll (from NSW 731813). d, e, male sporophyll (d, e, from NSW 728767). f, part of leaf. g, cross-section of leaflet (f, g, from NSW 728765). Scale bar: $\mathrm{a}=$ no scale, $\mathrm{b}, \mathrm{c}=6 \mathrm{~cm}, \mathrm{~d}, \mathrm{e}=2 \mathrm{~cm}, \mathrm{f}=10 \mathrm{~cm}, \mathrm{~g}=1 \mathrm{~cm}$. 


\section{Acknowledgments}

Mr. Kampon Tansacha the owner and Director of Nong Nooch Tropical Botanical Garden, Thailand is most gratefully acknowledged for his relentless encouragement and full sponsorship of the field trips. The Slade Foundation of Sydney is also thanked for assistance with travel and field studies. Stan Walkley, Wes Field and Mick Balaam from Plantation 2000 are thanked for cultivated material of C. nitida. We would also like to thank Dr. Edwino Fernando of the University of The Philippines, Los Baños. The staff of the Royal Botanic Gardens, Sydney, have been of invaluable assistance, and this would not have been published without them. Peter Wilson is thanked for assisting with the Latin and also for his helpful comments on the manuscript. Jeremy Bruhl is most gratefully thanked for locating type specimens (on short notice!) at Kew while Australian Botanical Liason Officer. Catherine Wardrop and Lesley Elkan are thanked for the illustrations.

\section{References}

Amoroso VB (1986) Morphological study of the sporophylls of Philippine Cycas. Philippine Journal of Science 115(3): 177-198.

Bonta M \& Osborne R (2007) Cycads in the Vernacular. In Vovides, A. et. al.(eds) Proceedings of the Seventh International Conference on Cycad Biology. Memoirs of New York Botanical Garden Vol. 97 (in press).

Brown WH \& Kienholz R (1925) Cycas chamberlainii, a new species. Philippine Journal of Science 26: 47-52.

De Candolle AP (1868) Cycadaceae. Pp. 522-548 in de Candolle AP (ed.) Prodromus Systematis Naturalis Regni Vegetabilis 16(2). (Masson: Paris)

De Laubenfels DJ \& Adema F (1998) A taxonomic revision of the genera Cycas and Epicycas gen. nov. (Cycadaceae). Blumea 43: 351-400.

Dehgan B \& Yuen CKH (1983) Seed morphology in relation to dispersal, evolution and propagation of Cycas. Botanical Gazette 144(3), 412-418.

Donaldson JS (2003) (ed.) Cycads. Status Survey and Conservation Action Plan. IUCN/SSC Cycad Specialist Group. (IUCN: Gland and Cambridge)

Fosberg FR \& Sachet M-H (1975) Flora of Micronesia, 1: Gymnospermae. Smithsonian Contributions to Botany 20: 1-15.

Foxworthy FW (1911) Philippine gymnosperms. The Philippine Journal of Science 6(3): $149-152$.

Hill KD (1993) abstract. Pp 15-16 in Programme for Cycad 93 Third International Conference on Cycad Biology. (Pretoria).

Hill KD (1994) The Cycas rumphii complex (Cycadaceae) in New Guinea and the Western Pacific. Australian Systematic Botany 7(5): 3-567.

Hill KD (1995) Infrageneric relationships, phylogeny and biogeography of the genus Cycas (Cycadaceae). Pp. 139-162, in Vorster P (ed.) CYCAD 93, The 3rd International Conference on Cycad Biology, Proceedings. (Cycad Society of South Africa: Stellenbosch).

Hill KD (1998) The Cycad Pages, Royal Botanic Gardens Sydney. http://plantnet.rbgsyd.nsw. gov.au/PlantNet/cycad/index.html

Hill KD (2004a) Character evolution, species recognition and classification concepts in the Cycadaceae. Pp. 23-44 in Walters T \& Osborne R (eds) Cycad classification concepts and recommendations. (CABI Publishing: Wallingford)

Hill KD (2004b) An analysis of morphological characters used in classification of the Cycadaceae. Pp 6-29 in Lindstrom AJ (ed.) The Biology, Structure \& Systematics of the Cycadales Proceedings of the Sixth International Conference on Cycad Biology, Thailand, 29 July-3 Aug, 2002. (The Nong Nooch Tropical Botanical Garden: Sattahip) 
Hill KD (2008) The genus Cycas (Cycadaceae) in China. Telopea 12(1): 71-118.

Hill KD \& Yang S-L(1999) The genus Cycas (Cycadaceae) in Thailand. Brittonia 51(1): 48-73.

Howard FW, Hamon A, McLaughlin M \& Weissling T (1999) Aulacaspis yasumatsui (Homoptera: Sternorrhyncha: Diaspididae), a scale insect pest of cycads recently introduced to Florida. Florida Entomologist 82: 14-27.

IUCN (2001). IUCN Red List Categories and Criteria : Version 3.1. IUCN Species Survival Commission. (IUCN: Gland and Cambridge)

Jarvis CE, Barrie FR, Allan DM \& Reveal JL (1993) A list of Linnaean generic names and their types. Regnum Vegetabile 127, 1-100.

Lemaire C (1864) L'Illustration Horticole vol XI: (F \& E Gyselynck: Gand)

Lindstrom AJ \& Hill KD (2007) The genus Cycas (Cycadaceae) in India. Telopea 11(4): 463-488.

McNeill J, Barrie FR, Burdet H-M, Demoulin V, Hawksworth DL, Marhold K, Nicholson DH, Prado J, Silva PC, Skog JE, Wiersema JH \& Turland NJ (2006) International Code of Botanical Nomenclature (Vienna), adopted by the Seventeenth International Botanical Congress, Vienna ,Austria, July 2005. Regnum Vegetabile 146. (Gantner: Ruggell)

Madulid DA \& Agoo EMG (2005) A new species of Cycas (Cycadaceae) from the Philippines. Blumea 50(3): 519-522.

Merrill ED (1912) A Flora of Manilla. (Bureau of Science: Manila)

Merrill ED (1917) An Interpretation of Rumphius's Herbarium Amboinense. (Bureau of Science: Manila).

Merrill ED (1918) Species Blancoanae. (Bureau of Science: Manila)

Merrill ED (1921) A bibliographic enumeration of Bornean plants. Journal of the Straits Branch of the Royal Asiatic Society, Straits, Special No. (Fraser \& Neave: Singapore)

Merrill ED (1923) An enumeration of Philippine flowering plants, vol. 1. (Bureau of Science: Manila)

Merrill ED (1936) A new Philippine species of Cycas. Philippine Journal of Science 50: 233-239.

Miquel, F.A.W. ( 1851) Analecta Botanica Indica. (Sulpke: Amsterdam)

Miquel FAW (1868) Nouveaux matériaux pour servir à la connaissance des Cycadées. Archives Néerlandaises des Sciences Exactes et Naturelles 3(5): 193-254, 403-427.

Pilger R (1926) Cycadaceae. Pp. 44-82 in Engler A (ed.) Die naturlichen pflanzenfamilien, edition 2, 13. (Duncker \& Humblot: Berlin)

Regel E (1863) Cycas riuminiana Porte. Gartenflora 12: 16-17.

Regel E (1876a) Cycadearum Generum Specierumque Revisio. (St Petersburg)

Regel E (1876b) Cycadearum Generum Specierumque Revisio. Acta Horti Petropilitani 4: 275320.

Ridley H (1925) Cycadaceae. Pp. 283-285 in Flora of the Malay Peninsula, 5. (Reeve \& Co. Ltd: London)

Schuster J (1932) Cycadaceae. Pp. 1-168, in Engler, A. (ed.) Das Pflanzenreich 99(4,1), 168.

Walter KS \& Gillett HJ (eds) (1998) 1997 IUCN Red List of Threatened Plants. Compiled by the World Conservation Monitoring Centre. (IUCN - The World Conservation Union: Gland)

Wang DY (1996) Systematic classification and taxonomy. Pp. 9-142 in Wang F-X \& Liang H-B (eds) Cycads in China. (Guangdong Science and Technology Press: Guangdong)

Warburg O (1900) Cycadaceae. Pp. 178-181 in Warburg O (ed.) Monsunia. (Engelmann: Leipzig)

Zamora PM \& Co L (1986) Guide to Philippine flora and fauna, vol. 2: descriptions of Gymnosperm species. (Ministry of Natural Resources \& University of the Philippines: Quezon City) 